\title{
ANALISIS RIWAYAT PENGGUNAAN BAHASA BILINGUAL DENGAN ANAK KETERLAMBATAN BICARA DI RS IMANUEL BANDAR LAMPUNG TAHUN 2019
}

\author{
Festy Ladyani ${ }^{1}$, Astri Pinilih ${ }^{2}$, Muhamad Faqih ${ }^{3}$ \\ ${ }^{1}$ Departemen Ilmu Gizi Medik, Fakultas Kedokteran, Universitas Malahayati \\ ${ }^{2}$ Departemen IImu Anak, Fakultas Kedokteran, Universitas Malahayati \\ ${ }^{3}$ Program Studi Kedokteran, Fakultas Kedokteran, Universitas Malahayati
}

\begin{abstract}
Analysis of Using Bilingual Language with Speech Delay in Imanuel Hospital Bandar Lampung at 2019. Speech delay is one aspect of language and speech development that requires attention. Speech and language disorders are one of the problems that often occured in children. With the influence of globalization as well as acculturation of Indonesian culture plus the lack of parental knowledge in parenting that can causes children to become speech delay. The main factors are using bilingual languages history and using of gadgets and television that aren't monitored by parents. To knowing the history of using bilingual languages for children with speech delay in Imanuel Hospital Bandar Lampung on 2019. Descriptive research with qualitative approach by using primary data type which was obtained directly from research informants. Collecting data used by researcher was using structural interview technique or open interview. This research was done during February 2019 at Imanuel Hospital Bandar Lampung. On this research, there were 2 sample and 2 informants. Researcher discovered there are a history of using more than 3 languages from family in home, technology, and school that can affect the language development of speech delay children. History of using the bilingual languages has an impact on children with speech delay.
\end{abstract}

Keywords: Bilingual language, children, speech delay.

\begin{abstract}
Abstrak: Analisis Riwayat Penggunaan Bahasa Bilingual dengan Anak Keterlambatan Bicara di RS Imanuel Bandar Lampung Tahun 2019. Keterlambatan berbicara merupakan salah satu aspek perkembangan bahasa dan bicara yang memerlukan perhatian. Gangguan bicara dan bahasa merupakan salah satu masalah yang sering terjadi pada anak-anak. Dengan masuknya globalisasi dan juga akulturasi budaya bangsa Indonesia yang kaya ditambah kurangnya pengetahuan orang tua dalam parenting sehingga menyebabkan anak menjadi speech delay. Faktor utamanya diantara lain yaitu riwayat penggunaan bahasa bilingual serta penggunaan gadget dan televisi yang kurang diawasi oleh orang tua. Tujuan penelitian ini untuk mengetahui riwayat penggunaan bahasa bilingual terhadap anak dengan keterlambatan bicara di RS Imanuel Bandar Lampung Tahun 2019. Penelitian deskriptif dengan pendekatan kualitatif dengan menggunakan jenis data primer yaitu data yang diperoleh langsung dari informan penelitian. Cara pengumpulan data yang penulis gunakan adalah melalui teknik wawancara terstruktur atau wawancara terbuka. Penelitian ini dilakukan selama bulan Februari 2019 di RS Imanuel Bandar Lampung. Pada Penelitian ini terdapat 2 sampel dan 2 informan. Diketahui ada riwayat penggunaan bahasa bilingual lebih dari 3 bahasa dari keluarga dirumah, teknologi, dan di sekolah yang berpengaruh dalam perkembangan bahasa anak dengan keterlambatan bicara. Riwayat penggunaan bahasa bilingual memiliki pengaruh terhadap anak dengan keterlambatan berbicara.
\end{abstract}

Kata Kunci : Bahasa bilingual, anak, keterlambatan bicara. 


\section{PENDAHULUAN}

Salah satu aspek perkembangan yang memerlukan perhatian adalah perkembangan bahasa dan bicara. Gangguan bicara dan bahasa merupakan salah satu masalah yang sering terjadi pada anak-anak. Menurut CHS berdasarkan laporan orang tua, angka kejadiannya adalah $0,9 \%$ pada anak dibawah umur 5 tahun, dan 1,94\% pada anak yang berumur 5-14 tahun. Hasil evaluasi langsung terhadap anak usia sekolah angka kejadiannya 3,8 kali lebih tinggi. Hal ini diperkirakan gangguan bicara dan bahasa pada anak adalah sekitar 4-5\%. Perkembangan bicara dan bahasa merupakan indikator seluruh perkembangan anak, karena perkembangan berbahasa sensitif terhadap keterlambatan atau kerusakan pada sistem lainnya sebab melibatkan perkembangan kognitif, sensori motorik, psikologis, emosi dan lingkungan di sekitar anak (Soetjiningsih, 2013).

$$
\text { Berdasarkan }
$$

skrining perkembangan yang dilakukan Depkes RI tahun 2003 pada 30 provinsi di Indonesia didapatkan bayi yang mengalami keterlambatan perkembangan adalah 45,12\% (Christiari, dkk, 2013).

Pada tahun 2016 di Puskesmas Kedaton tercatat terdapat sebelas balita yang mengalami gangguan tumbuh kembang, dua balita mengalami gangguan perkembangan motorik, delapan balita mengalami gangguan perkembangan bahasa (delayed speech) dan satu balita mengalami gangguan tumbuhkembang (Puskesmas Kedaton, 2016)

$$
\text { Dwibahasa (bilingualism) }
$$

adalah kemampuan menggunakan dua bahasa. Kemampuan ini tidak hanya dalam berbicara dan menulis tetapi juga kemampuan memahami apa yang dikomunikasikan orang lain, baik secara lisan maupun tertulis.
METODE

Rancangan penelitian ini menggunakan desain penelitian deskriptif dengan pendekatan kualitatif. Pengolahan dan analisis data menggunakan Teknik Triangulasi Data berarti teknik pengumpulan data dari tiga sudut yang berbeda. Triangulasi adalah teknik pemeriksaan keabsahan data yang memanfaatkan sesuatu diluar data itu untuk keperluan pengecekan atau sebagai pembanding terhadap data itu (Notoatmojo, 2002). Penelitian ini dilaksanakan pada bulan Februari 2019 sampai selesai. Penelitian ini dilaksanakan di Rumah Sakit Imanuel Bandar Lampung.

\section{HASIL}

\section{Fokus 1 Gambaran Tentang Riwayat Penggunaan Bahasa Bilingual Terhadap Anak Dengan Speech Delay}

Pada penelitian ini peneliti melakukan in-depth interview kepada 2 orang dewasa yang merupakan orang tua dari 2 pasien anak speech delay dan dijadikan sebagai informan dalam penelitian ini.

\section{Riwayat Kelahiran sebagai Faktor Resiko}

Pada point pertama ini peneliti akan menjelaskan tentang jawaban dari informan mengenai riwayat kelahiran anaknya.

Berdasarkan hasil dari wawancara dengan Informan 1 menyatakan bahwa : "Untuk anak saya lahirnya sectio caesar, tidak mengalami berat badan lahir rendah (BBLR) juga, karena lahirnya sekitar 2700 gram, selama kehamilan juga saya tidak pernah ada masalah seperti anemia, dll. Semuanya berjalan normal kecuali pada saat lahirnya saja". (Inf. C).

Berdasarkan hasil dari
wawancara dengan Informan 2
menyatakan bahwa :


"Saya pada saat melahirkan anak saya melalui persalinan normal, anak saya juga tidak memiliki masalah berat badan pada saat lahir, berat badannya pada saat lahir 2900 gram. Untuk riwayat kehamilan saya tidak ada masalah, tidak ada mengalami anemia selama kehamilan dan nampak baik - baik saja". (Inf. F)

Berdasarkan hasil dari wawancara diatas dapat dilihat bahwa kedua informan memiliki riwayat yang berbeda pada saat proses persalinan, namun memiliki kesamaan pada anaknya yakni keduanya tidak mengalami berat badan lahir rendah (BBLR) dan tidak ada riwayat anemia ataupun kelainan lainnya selama kehamilan. Menurut Hidajati (2009) menjelaskan bahwa anemia merupakan kadar hemoglobin ibu yang rendah, sehingga suplai darah ke janin turun dan menyebabkan berkurangnya suplai oksigen ke otak janin. Kebutuhan oksigen yang tidak terpenuhi dengan baik dapat mengakibatkan gangguan perkembangan otak, namun pada kedua informan di atas menjelaskan bahwa keduanya tidak pernah mengalami anemia. Lalu persalinan dengan tindakan seperti vakum ekstraksi, forsep, atau operasi sectio caesar dapat terjadi kompresi negatif pada kepala bayi di daerah fronto oksipital dan mengakibatkan pemanjangan diameter fronto oksipital. Akibatnya dapat terjadi regangan terhadap falks, tentorium dan sinus tempat vena gallen bermuara sehingga dapat menyebabkan robekan pada vena gallen dan perdarahan subdural. Adanya perdarahan dapat mengakibatkan gangguan aliran darah sehingga terjadi gangguan transpor glukosa dan oksigen menuju otak. Namun yang peneliti temui dilapangan hanya informan 1 (Inf. C) yang mengalaminya, namun tidak pada informan 2 (Inf. F). Dan selanjutnya Bayi berat badan lahir rendah (BBLR) adalah bayi yang lahir dengan berat badan kurang dari 2500 gram (sampai 2.499 gram). Bayi berat lahir rendah dapat disebabkan karena dismaturitas. Prognosis pada tumbuh-kembang termasuk perkembangan bahasa pada bayi kecil untuk masa kehamilan (KMK) kurang baik daripada bayi prematur, karena pada KMK telah terjadi retardasi pertumbuhan sejak didalam kandungan, lebih-lebih jika tidak mendapat nutrisi yang baik sejak lahir. Penyebab dismaturitas adalah setiap keadaan yang mengganggu pertukaran zat antara ibu dan janin, sehingga menyebabkan kebutuhan oksigen dan glukosa bayi dalam kandungan tidak terpenuhi dengan baik. Pada akhirnya kebutuhan yang tidak terpenuhi mengakibatkan gangguan perkembangan otak.

Namun pada penelitian yang ditulis Dewanti (2016) menjelaskan bahwa sebanyak $93.5 \%$ pasien terlambat bicara memiliki berat badan normal pada saat lahir, yang artinya itu itu sesuai dengan yang peneliti temui di lapangan. Dan sebanyak 95 $\%$ pasien lahir normal, lalu sebanyak $72.3 \%$ status gizi yang baik selama kehamilan yang mana sesuai dengan yang peneliti temui di lapangan.

\section{Riwayat Speech Delay}

Pada point kedua ini peneliti akan menjelaskan tentang respon dari informan mengenai cerita tentang pasien yang terdiagnosa speech delay.

Berdasarkan hasil dari wawancara dengan Informan 1 menyatakan bahwa :

"Pada saat itu anak saya baru berusia sekitar 1,5 tahun dan cuma bisa memanggil Maaa.... Pa.... dan kalau mau meminta sesuatu hanya bersuara tanpa arti sambil menunjukkan sesuatu yang dia mau dan tidak bisa mengambil benda kecil seperti kacang, kismis, dll. Namun, sampai umur 2 tahun anak saya pun masih sama, tidak ada perbedaan dan tidak ada perkembangan yang saya 
lihat. Sejak dari itu, baru saya ajak ke dokter lalu dokter bilang anak saya mengalami speech delay". (Inf. C)

Berdasarkan hasil dari
wawancara dengan Informan 2
menyatakan bahwa :

"Anak saya pada saat itu sama pengasuh, karena saya kerja dan suami saya kerja. Tapi saya mulai tahu itu mulai sekitar 2 tahun 2 bulan karena saya lihat anak saya banyak diam. Memang kebetulan waktu itu saya juga masih banyak diam begitu juga suami saya. Jadi anak saya itu hanya bisa bilang 'Ma' dan 'Pa' dan juga kalau menginginkan sesuatu tidak bisa berkata, lebih ke bahasa isyarat, seperti itu. Saya menyadari bahwa ini kelainan, jadi waktu itu saya bawa ke dokter dan dokter bilang speech delay". (Inf F)

Berdasarkan dari hasil wawancara di atas dapat kita lihat bahwa dari kedua responden ini menyatakan anaknya mengalami keterlambatan berbicara ketika berusia sekitar 2 tahun, namun pada informan 1 (Inf. C) ia sudah mulai berpikir bahwa anaknya mengalami keterlambatan berbicara sejak usia 1,5 tahun. Menurut Glascoe (2010), banyak anak yang mengalami keterlambatan berbicara pada usia 24 bulan - 30 bulan dan hal ini dapat dilihat dari kemampuan anak sebayanya berbicara. Jika tidak sama, bahkan jauh maka patut dicurigai sebagai speech delay. Menurut Hurlock (2013) dikatakan terlambat bicara apabila tingkat perkembangan bicara berada di bawah tingkat kualitas perkembangan bicara anak yang umurnya sama yang dapat diketahui dari ketepatan penggunaan kata. Serta dalam Anggraini (2011) dikatakan apabila pada saat teman sebaya mereka berbicara dengan menggunakan kata-kata, sedangkan si anak terus menggunakan isyarat dan gaya bicara bayi maka anak yang demikian dianggap orang lain terlalu muda untuk diajak bermain. Dan dari Depkes RI (2010) anak usia 24 bulan seharusnya sudah dapat mengucapkan paling sedikit 3 kata yang mempunyai arti selain 'papa' dan 'mama' bahkan kemampuan ini sudah bisa muncul ketika usia 21 bulan. Namun pada penelitian sebelumnya yang telah ditulis oleh Tsuraya (2013), mengatakan bahwa anak yang mengalami keterlambatan bicara berusia prasekolah dan sekolah. Anak prasekolah berusia 3-6 tahun, sedangkan anak usia sekolah 7-12 tahun. Keterlambatan bicara pada anak usia 3 tahun antara lain belum mengerti kalimat, tidak mengerti perintah verbal dan ada yang tidak memiliki minat bermain dengan sesamanya. Anak berusia 3,5 tahun tidak dapat menyelesaikan kata seperti "ayah" yang diucapkan dengan kata "aya". Anak berusia 4 tahun masih gagap dan tidak dapat dimengerti secara lengkap. Pada penelitian ini menyebutkan bahwa speech delay ditemukan pada anak usia 3 tahun, namun yang peneliti temui dilapangan bahwa anak speech delay ini sudah bisa terdeteksi sejak usia 2 tahun.

\section{Riwayat Penggunaan Bahasa Di Rumah}

Pada point ketiga ini peneliti akan menjabarkan jawaban dari informan mengenai riwayat penggunaan bahasa bilingual dirumah.

Pada kesempatan kali ini Informan 1 menjelaskan bahwa: "Untuk dirumah sebenarnya memakai bahasa indonesia tapi karena ayahnya orang batak, jadi sering menggunakan bahasa batak juga, lalu neneknya orang lampung pakai bahasa lampung juga, karena saya sama suami kerja jadi anak sering bersama neneknya. Lalu neneknya sakit, anak saya diasuh sama pengasuh, dan cukup lama sampai 1 tahunan, dan 


\author{
kebetulan pengasuh pakai \\ bahasa jawa". (Inf. C)
}

Pada kesempatan kali ini Informan 2 menjelaskan bahwa: "Saya pendatang dari Bandung jadi pada saat di Bandar Lampung sudah pasti Bahasa yang digunakan berbeda, mulai dari dialek, logat, dan lain sebagainya.

Dirumah saya pakainya bahasa sunda, suami saya bahasa jawa terkadang bahasa padang sampai bahasa palembang juga, terkadang saya juga tidak mengerti apa yang dikatakan suami saya. Dan kebetulan memang lebih mengikuti bahasa saya, yaitu bahasa sunda tapi anak saya juga dari bayi sampai usia 1,5 tahun lebih diasuh sama pengasuh, dan sering sekali berganti - ganti pengasuh, dan kebetulan pengasuh juga bahasanya berbeda, ada yang pernah bahasa bali, bahasa jawa, dan bahasa - bahasa lain serta jarak ganti pengasuhnya pun cukup dekat ada yang Cuma 1 minggu, tapi paling lama ada yang hampir 1 bulan". (Inf. F)

Berdasarkan hasil dari wawancara bersama 2 informan di atas dapat dikatakan bahwa kedua sample ini memang benar adanya menggunakan bahasa sehari - hari yang lebih dari 1 bahasa. Menurut Kridalaksana (2007), didalam Mardiana (2016) menyatakan bahwa Bilingual merupakan kemampuan seseorang dalam menggunakan dua bahasa dalam perkataan dan pemaknaannya. Anak yang memiliki kemampuan dwibahasa memahami bahasa asing dengan baik seperti halnya pemahaman anak terhadap bahasa ibunya. Anak mampu berbicara, membaca, dan menulis dalam dua bahasa dengan kemampuan yang sama. Sebenarnya hanya sedikit anak yang berkemampuan dwibahasa. Sebagian besar lebih pandai menggunakan bahasa yang satu dibandingkan bahasa yang lainnya. Pada waktu anak diharapkan mempelajari dua bahasa secara serempak, mereka harus mempelajari dua kata yang berbeda untuk setiap obyek yang mereka sebutkan dan untuk setiap pikiran yang ingin mereka ungkapkan. Mereka harus mempelajari dua perangkat bentuk tata bahasa, yang sering kali bertentangan satu sama lain. Tugas belajar tersebut sangat membingungkan anak yang belum mempelajari salah satu bahasa dengan cukup baik sehingga merasa sukar melakukannya. Bagi sebagian anak, dwibahasa merupakan gangguan yang serius untuk belajar berbicara dengan benar. Dapat disimpulkan bahwa kedwibahasaan lebih merupakan hambatan ketimbang kelebihan bagi anak, khususnya tahun-tahun prasekolah. Dan pada hasil wawancara bersama informan diatas dapat kita lihat bahwa anak yang bersangkutan harus memahami banyak bahasa, yang mana menurut teori hal itupun dapat membuat anak bingung dalam mempelajarinya sehingga menjadi suatu hal menganggu yang cukup serius. Dan pada penelitian sebelumnya yang ditulis oleh Ritonga dkk. (2018) yang mengatakan bahwa: "Ini mirip dengan hasil kami, di mana dalam lingkungan bilingual ada anakanak yang mengalami gangguan perkembangan bahasa Indonesia berdasarkan hasil skrining skrining perkembangan bahasa Indonesia CAT / CLAMS. dalam penelitian ini, kemungkinan gangguan bahasa Indonesia di lingkungan bilingual 1,1 kali lebih besar dari lingkungan nonbilingual. Dalam hal ini lingkungan bilingual salah satu faktor lingkungan yang mempengaruhi perkembangan bahasa".

Sedangkan menurut Mardiana (2016) terdapat hubungan yang signifikan terhadap bilingual dengan perkembangan bahasa anak usia toddler di KB Aisyiah Bae Kabupaten Kudus yaitu sebanyak 2,1 kali dibandingkan dengan lingkungan yang tidak bilingual. Dan dari hasil 
penelitian tersebut memang benar adanya bahwa penggunaan bahasa bilingual dapat menyebabkan gangguan dalam perkembangan berbahasa anak. Dan dari hasil penelitian yang ditemukan peneliti bahwa 2 anak speech delay dari 2 informan diatas memang menggunakan bahasa bilingual bahkan lebih dari 2 bahasa, sehingga menyebabkan efek bingung pada anak saat mempelajari kata - kata yang didengarnya.

\section{Riwayat Penggunaan Bahasa Bilingual Di Lingkungan Luar}

Di point keempat ini peneliti akan menjelaskan hasil wawancara bersama kedua informan tentang penggunaan bahasa bilingual dilingkungan luar.

Pada kesempatan kali ini Informan 1 menyatakan bahwa: "Anak saya pernah saya masukkan ke sekolah, seperti playgroup dan memang di sekolah itu Bahasa yang digunakan Bahasa Inggris dan Bahasa Indonesia. Keduanya seimbang tidak ada yang terlalu dominan. Sekolahnya memang dua bahasa, dan juga untuk interaksi bersama teman temannya tidak terlalu sering, karena dia merasa asing, sehingga anak saya pun pada akhirnya main sendiri". (Inf. C)

Pada kesempatan kali ini Informan 2 menyatakan bahwa: " Pada saat itu ketika anak saya sudah tidak bersama pengasuh lagi, tapi saya juga masih sibuk kerja jadi saya masukkan anak saya ke sekolah saja. Sejenis playgroup sekolahnya, dan disana kebetulan bahasa yang dipakai Bahasa Inggris dan juga Bahasa Indonesia, 2 bahasa itu yang digunakan di sekolah. Untuk dominannya juga sama aja, tidak ada yang terlalu dominan, hampir sama rata presentase penggunaannya. Jadi disana seperti mengucapkan Bahasa Inggris terlebih dahulu, lalu baru menyebutkan artinya dalam Bahasa Indonesia seperti menyebutkan plate yang mana artinya adalah piring, seperti itu. Untuk interaksi bersama teman teman anak saya lebih sering diam, karena memang pertama bahasanya beda, anak saya mengikuti saya Bahasa Sunda, dan lalu disini sangat berbeda bahasanya, sehingga mungkin menimbulkan rasa tidak percaya diri pada anak saya untuk berbicara bersama temannya". (Inf. F)

Dilihat dari hasil di atas menunjukkan bahwa penggunaan bahasa bilingual disekolah juga merupakan faktor penyebab dari speech delay, dan membuat anak semakin tidak percaya diri karena perbedaan bahasa dengan lingkungan sekitar. Dari tinjauan teori :

"Sistem pemrosesan wicara yang mendasari keterampilan ini terdiri dari sisi input untuk menerima informasi yang diucapkan dan sisi output untuk memilih dan menghasilkan kata-kata dan kalimat yang diucapkan. Selain itu, anak perlu menyimpan informasi linguistik tentang bahasa lisan dalam berbagai representasi dalam leksikon (penyimpan kata-kata pengetahuan) (Bishop, 2014). Jika ada 2 atau lebih bahasa yang dimiliki anak, itu mungkin menjadi masalah. terutama pada periode prasekolah, karena anak masih memproduksi apa yang mereka dengar untuk disampaikan dari apa yang mereka inginkan kepada orang tua mereka atau orang lain, dan dengan 2 atau lebih bahasa yang mereka miliki, sulit bagi mereka untuk menerima informasi lisan dan menghasilkan kata-kata dan kalimat lisan jika bahasa mereka yang sudah mereka miliki lebih dari satu bahasa. itu dapat membuat anak-anak bingung ketika mereka ingin berbicara kadang-kadang agak berbeda dengan situasi bahasa saat ini".

Dari hal di atas peneliti menyimpulkan bahwa bilingual dilingkungan luar juga mempengaruhi 
perkembangan berbahasa anak. Dan pada penelitian sebelumnya yang pernah ditulis oleh Pusponegoro, (2014) yang disimpulkan bahwa penggunaan dua bahasa atau lebih di rumah maupun dilingkungan luar rumah seperti sekolah, taman bermain, dll. Pada anak normal tidak menimbulkan masalah. Anak dengan kemampuan bilingual dapat menguasai kedua bahasa tersebut sebelum berusia 6 tahun (Barac, 2012). Lingkungan yang bilingual baik untuk anak normal, tetapi sebaliknya dapat menghambat kemajuan anak yang memang sudah mengalami keterlambatan berbicara dan pada akhirnya tidak berinteraksi dengan sekitar dan makin menghambat perkembangan berbicaranya. Dari sana peneliti mengambil garis besar bahwa memang benar bilingual dilingkungan luar pun dapat menghambat kemajuan anak yang memang sudah mengalami keterlambatan berbicara, dan menjadikan anak menjadi makin tidak percaya diri untuk berinteraksi dengan lingkungan sekitar.

\section{Pengaruh Perkembangan Teknologi Dengan Anak Speech Delay \\ Pada point kelima ini peneliti akan menjelaskan bahwa kemajuan teknologi juga dapat berpengaruh pada anak yang mengalami speech delay.}

Informan 1 menjelaskan bahwa : "Anak saya sangat sering memainkan handphone, yang dimainkan seperti games barbie seperti ganti baju dan bahasa didalamnya bahasa inggris seandainya tidak diberikan handphone maka anak saya akan menangis, lalu selain itu sering menonton youtube juga seperti film film princess dan bahasa inggris juga, lalu untuk durasinya satu hari cukup lama, mungkin bisa 4 jam lebih. Untuk film dirumah juga yang sering ditonton upin ipin yang mana itu merupakan bahasa malaysia". (Inf. C)

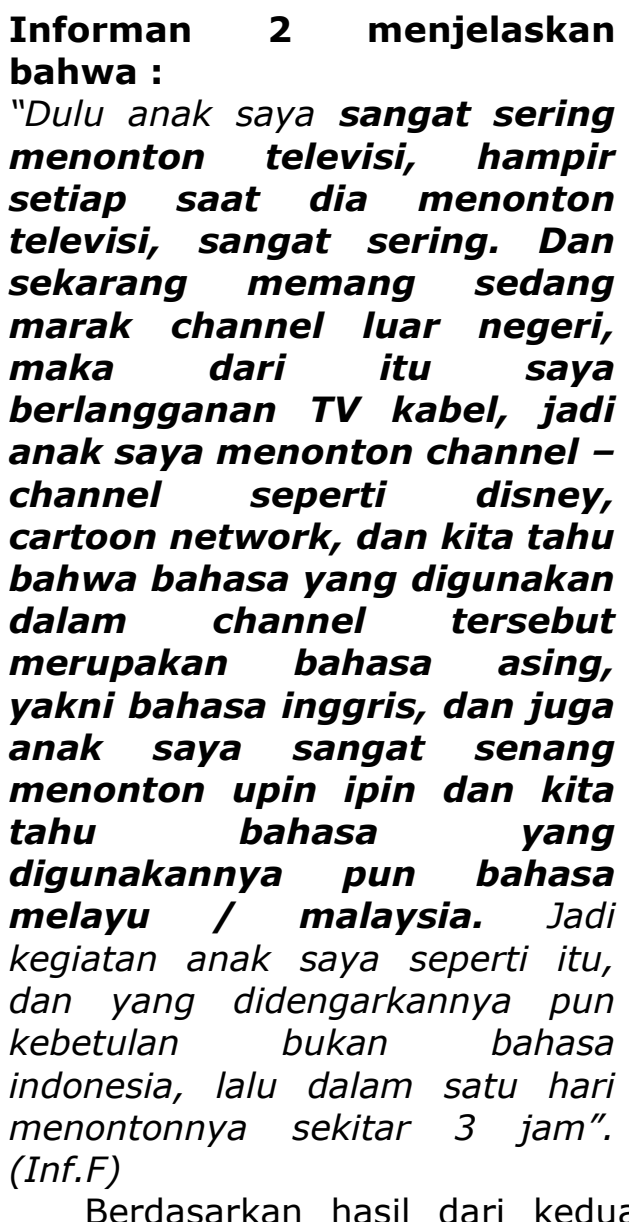
informan di atas menyatakan bahwa anak mereka sudah terbiasa dengan menonton televisi dan juga gadget atau handphone dan mereka pun sudah terdoktrin dengan bahasa bahasa asing dari televisi ataupun gadget yang mereka gunakan. Menurut Suhartini, (2017):

"Di era digital ini, banyak orang tua menganggap telah memfasilitasi anak-anak dengan TV dan gadget. Praktik yang umum adalah bahwa jika anak itu cerewet dan tidak dapat dikendalikan, orang tua mengasumsikan bahwa itu sudah cukup untuk menyediakan permainan melalui gadget atau menyalakan TV untuk bahan pengalihan. Anak memang akan berhenti rewel, tetapi minat lebih lanjut akan terbentuk pada barang elektronik. Jadi di lain waktu, itu akan membebani aktivitas bermain game atau menonton TV dan 
akan cerewet jika tidak diberikan. Jika Anda terus mematuhinya, anak Anda menjadi kecanduan. Anak - anak yang kecanduan menggunakan gadget akan terhambat aspek perkembangannya, terutama pada pengembangan wicara".

Dari hasil tinjauan teori di atas menunjukkan bahwa dengan kemajuan teknologi yang tidak diimbangi oleh pengawasan orang tua dengan baik ditambah minimnya pengetahuan tentang parenting maka dapat menyebabkan gangguan pada perkembangan berbicara pada anak, ditambah lagi perbedaan bahasa yang digunakan pada gadget dan televisi yang mana itu sendiri dapat menyebabkan gangguan juga pada anak. Menurut The American Academy of Pediatrics (AAP) menyarankan bahwa untuk penggunaan media berbasis layar untuk anak tidak lebih dari 1 sampai 2 jam per hari, namun yang peneliti temui di lapangan bahwa kedua informan menggunakan hal tersebut lebih dari 2 jam per hari.

Dan dilihat dari penelitian sebelumnya yang telah dilakukan oleh Gunawan (2017) mengatakan bahwa : "Selanjutnya, hal menarik lainnya dari persepsi ayah tentang keterlambatan bicara yang terjadi pada anak adalah persepsi mereka tentang penyebab keterlambatan bicara. Secara langsung, ada responden yang percaya bahwa televisi menjadi instrumen yang menyebabkan anak mengalami keterlambatan bicara. "Kebetulan, itu salah kami. Ketika putra saya berusia satu tahun, istri saya hamil. Dia tidak diizinkan menggendong putraku. Sementara pada saat itu putra saya sangat melekat pada ibunya. Saya mulai menyalakan TV untuk anak saya. Jadi semuanya dimulai. Sejak saat itu, putra saya selalu meminta untuk menonton TV ". (Pak Yayan di Bandung). Dengan mengatakan, "Sejak saat itu, anak saya selalu meminta untuk menonton TV", kita dapat memahami bahwa TV pada awalnya adalah alat untuk kompensasi sementara untuk menghibur dan pada akhirnya, itu menjadi kebutuhan bagi anak. Di sini, Pak Yayan mencoba mengatakan bahwa pada akhirnya putranya meminta untuk secara teratur menyalakan televisi sebagai bagian dari kehidupan anak, dan melihat bahwa televisi adalah penyebab keterlambatan bicara yang dialami putranya. Selain televisi, salah satu responden lain secara tidak langsung mengatakan bahwa gadget dalam hal ini ponsel juga ternyata telah mempengaruhi perilaku anak. "Jika dia melihat ponsel saya, dia selalu mengambil ponsel saya". (Bpk. Yayan, Bandung). Tujuan kalimat di atas, tentu saja, adalah ketika ayah memegang ponsel, dan kemudian anak akan datang untuk mengambil dan memainkan telepon. Dari pernyataan di atas, kita dapat menganalisis bahwa putranya akrab dengan gadget" (Gunawan, 2017).

Dan dari penelitian yang dilakukan oleh Gunawan (2017) di atas dapat peneliti simpulkan bahwa memang benar adanya jika penggunaan gadget dan televisi yang berlebihan serta tanpa pengawasan bahasa didalamnya dapat menyebabkan gangguan. Terutama jika telah disuguhkan sejak dini, ditambah lagi dengan semakin majunya teknologi dan derasnya aliran globalisasi maka gadget serta televisi pun telah menjadi kebutuhan primer bagi sebagian masyarakat. Dan pada penelitian ini dijelaskan oleh informan 1 (Inf. C) dan informan 2 (Inf. F) bahwa anak mereka memang terlalu sering pada memainkan gadget dan televisi serta bahasa didalamnya pun merupakan bahasa asing.

\section{Penggunaan Bahasa yang Seragam Dapat Memperbaiki Kondisi Anak Speech Delay}

Pada point keenam ini peneliti
akan menjelaskan mengapa
penggunaan bahasa yang
seragam dapat memperbaiki
kondisi anak dengan speech
delay.


Hal ini dibuktikan dengan keterangan Informan 1 yang mengatakan bahwa : "Anak saya sekarang sudah sangat bagus kemajuannya, kemampuan berbahasanya pun sudah sama seperti anak seusianya. Karena saya rutin mengajak anak saya terapi, mungkin tidak sampai 1 tahun. Dan yang paling ditekankan oleh dokter dan terapis RS Imanuel Kota Bandar Lampung adalah dukungan dari orang tua serta pemilihan bahasa yang seragam di rumah dan juga lingkungan luar rumah serta minat anak kami dalam pemilihan bahasa. Dan anak kami pun lebih memilih bahasa indonesia sebagai bahasa yang diminati, jadi dalam melakukan terapi pun terapisnya menggunakan bahasa indonesia, dirumah juga menggunakan bahasa indonesia, serta sekolahnya pun menggunakan bahasa indonesia. Untuk main handphone sendiri perlahan dikurangi dan sekarang anak saya jauh lebih baik dari sebelum sebelumnya". (Inf. C)

Hal ini dibuktikan dengan keterangan Informan 2 yang mengatakan bahwa : "Sekarang anak saya sudah normal seperti anak - anak lain yang seusianya, saya rutin terapi selama 6 bulan dan anak saya sekarang sudah sangat luar biasa perkembangannya, anak saya sangat cerewet sekarang. Saran dokter dan terapis bahwa saya dan suami saya harus lebih aktif dalam berkomunikasi dirumah, karena dokter bilang anak saya harus didukung juga untuk terapi dirumahnya. Jadi kami putuskan untuk menggunakan bahasa full indonesia didalam rumah, serta anak saya, saya pindahkan sekolahnya ke sekolah yang hanya berbahasa indonesia. Saya sengaja memilih bahasa indonesia karena lingkungan sekitar juga
menggunakan bahasa tersebut,
dan untuk televisi sudah
digunakan bahasa indonesia,
walaupun perlahan - lahan
menggantinya". (Inf. F)

Berdasarkan hasil wawancara bersama kedua informan di atas membuktikan bahwa memang terapi rutin serta keseragaman penggunaan bahasa dapat memperbaiki kondisi anak dengan speech delay. Pusponegoro (2014) menjelaskan bahwa pemakaian bahasa di rumah sebaiknya diseragamkan sehingga dapat membantu anak menguasai satu bahasa terlebih dahulu. Pengalaman menunjukkan bahwa mengajarkan orang tua untuk bermain dan berinteraksi dengan anak sangat membantu pada kasus keterlambatan bahasa ekspresif. Serta secara klinis, bila ada keterlambatan berbicara strategi bilingualisme harus didiskusikan dengan orang tua. Tentukan bahasa yang paling diperlukan dan tentukan kemampuan serta minat anak dalam bahasa. Dari beberapa hal yang telah dipaparkan di atas menunjukkan bahwa dengan metode penggunaan keseragaman bahasa memiliki efek yang sangat baik untuk membantu perkembangan anak yang terlambat berbicara, peneliti tidak terlalu menyinggung untuk pemilihan terapi yang diberikan karena pada penelitian ini hanya fokus pada penggunaan bahasa pada lingkungan anak yang bersangkutan. Menurut penelitian sebelumnya yang telah ditulis Ahmad (2016) bahwa orang tua harus melatih anak berbicara, pelan, dan berulang - ulang, lalu memperhatikan tata bahasa yang diucapkan anak saat berbicara, memperhatikan bahasa yang digunakan dalam melatih anak, disarankan untuk menggunakan bahasa yang sama dengan bahasa yang lebih dikuasai anak agar 
mampu memberikan hasil yang tua lah yang mendorong anak - anak untuk berbicara dengan tata bahasa yang benar.

Dari penelitian sebelumnya hingga penelitian yang peneliti lakukan menunjukkan bahwa memang orang tua yang memiliki peran penting, dan juga keseragaman bahasa atau pemilihan satu bahasa yang sama sangat membantu perkembangan anak yang mengalami speech delay.

\section{SIMPULAN}

\begin{tabular}{lrr}
\multicolumn{2}{c}{ Berdasarkan } & hasil \\
penelitian & dan & pembahasan \\
tentang & Analisis & Riwayat \\
Penggunaan & Bahasa & Bilingual
\end{tabular} Dengan Anak Keterlambatan Bicara Di RS Imanuel Bandar Lampung yang didapat dari informan yaitu orang tua pasien, maka didapatkan :

Diketahui ada riwayat penggunaan bahasa bilingual lebih dari 3 bahasa dari keluarga dirumah, teknologi, dan disekolah yang berpengaruh dalam perkembangan bahasa anak speech delay

\section{DAFTAR PUSTAKA}

Ahmad, A. and Fitriani, D., (2016). Model Pengembangan Kecakapan Berbahasa Anak Yang Terlambat Berbicara (Speech Delay). Jurnal IImiah Mahasiswa Pendidikan Anak Usia Dini, 1(1).

Anggraini, W., 2011.Keterlambatan Bicara (Speech Delay) Pada Anak (Studi Kasus Anak Usia 5 Tahun) (Doctoral dissertation, Universitas Negeri Semarang).

Barac, R. and Bialystok, E., (2012). Bilingual effects on cognitive and linguistic development: Role of language,cultural background, and education. Child development, 83(2), pp.413-422.

Bishop, D.V. and Leonard, L. eds., (2014). Speech and language impairments in children: Causes, baik, karena pada dasarnya orang characteristics intervention anoutcome. Psychology press.

DepKes, R.I., (2010). Pedoman pelaksanaan stimulasi, deteksi dan intervensi dini tumbuh kembang anak di tingkat pelayanan kesehatan dasar. DepKes RI.

Glascoe, F.P. and Leew, S., (2010). Parenting behaviors, perceptions, and psychosocial risk: impacts on young children's development. Pediatrics,125(2),pp.313,319.

Gunawan, I. and Nurihsan, A.J., (2017). The analysis of father's perspectives on child with speech delay.

Hurlock, EB. (2013). Perkembangan Anak Jilid 1. Jakarta: Erlangga.

Mardiana, S.S., (2016). Komunikasi Orangtua dan Bilingual Berhubungan dengan Perkembangan Bahasa pada Anak Usia Todller.

Pusponegoro, H.D., (2014). What to do when you find a child with speech and language delay.

Rahayu, IT dan Ardani AR. (2004). Observasi dan Wawancara. Jawa Timur: Bayumedia Publishing.

Ritonga, D.H., Sofyani, S. and Irsa, L., (2018). May. Relationship between Bilingual Environment and Indonesian Language Development in Children. In International Seminar on Public Health and Education 2018 (ISPHE 2018). Atlantis Press.

Soetjiningsih, IG. N. Gde Ranuh, (2013). Tumbuh Kembang Anak Edisi 2. Jakarta : EGC

Suharti, S., (2017). December. Regular Habits and a Conducive Environment in The Treatment of Children with Delayed Speech Development. In International Conference of Early Childhood Education (ICECE 2017). Atlantis Press.

Tsuraya, I. (2013). Kecemasan Pada Orang Tua Yang Memiliki Anak Terlambat Bicara (Speech Delay) Di RSUD Dr. M. Ashari Pemalang (Doctoral dissertation, UN). 